\title{
SHORT COMMUNICATION: SIMPLIFIED APPROACH FOR EARLY IDENTIFICATION OF SPONTANEOUS OIL PALM HAPLOID (Elaeis guineensis)
}

\author{
MUHAMMAD AZWAN, Z*; ZAKI, N M*; NORDIANA, H M N*; MADON, $M^{\star *}$; NORZIHA, A*; ZULKIFLI, $Y^{*}$, \\ CHAN, $\mathrm{PL}^{*}$ and SINGH, $\mathbf{R}^{*}$
}

\begin{abstract}
Haploid technology facilitates the production of completely homozygous plants that are desirable in crop breeding. Having just one complete set of chromosomes in a haploid individual allows it to be doubled to produce a normal but pure $2 n$ diploid plant. Here, we report a simple way to identify natural haploids of oil palm (Elaeis guineensis Jacq.) from screening 6400 abnormal germinated seeds. Initially, the germinated seeds were selected based on 12 unique 'off-type' morphological characteristics. The selected seeds were then grown and the seedlings were subjected to a second selection for three distinctive characteristics. Ploidy analysis with flow cytometry (FCM) and chromosome karyotyping confirmed the haploidy of one seedling with stunted height and size. Further analysis with the True-to-Type single nucleotide polymorphism (SNP) panel demonstrated that the plant was homozygous at all the loci tested, confirming its haploid status. This study has established a simple and systematic strategy that assists in accelerating early identification of oil palm spontaneous haploid.
\end{abstract}

Keywords: Elaeis guineensis, haploid, abnormal germinated seed.

Received: 4 November 2020; Accepted: 19 January 2021; Published online: 4 May 2021.

\section{INTRODUCTION}

Haploids are a valuable source in crop improvement (Germana et al., 2011), widely used by doubling up to produce homozygous diploids rapidly. This increases selection efficiency in the F1 generation and overcomes inbreeding depression, all in all, to shorten the breeding cycle in conventional breeding (Dwivedi et al., 2015). Doubled haploid breeding is becoming an important tool in many programs, such as in brassicas (Xu et al., 2007) and maize (Chaikam et al., 2019). Due to the complete homozygosity of doubled haploid lines,

\footnotetext{
Malaysian Palm Oil Board,

6 Persiaran Institusi, Bandar Baru Bangi,

43000 Kajang, Selangor, Malaysia.

E-mail: hariza@mpob.gov.my

** 9, Jalan BM 5/12, Bandar Bukit Mahkota, 43000 Kajang, Selangor, Malaysia.
}

the technology is also highly desirable for molecular and gene mapping research (Chaikam et al., 2019).

The occurrence of spontaneous haploids that are naturally derived without any manipulation is frequently discovered in small frequency (Chase et al., 1969; Dunwell et al., 2010). The first natural haploid was a weed reported by Dorothy Bergner (Blakeslee, 1922), then in tobacco, peach and wheat (Kostoff, 1929; Yahata et al., 2005; Forster et al., 2007). In oil palm, about $0.02 \%$ spontaneous haploids were identified from 60 millions abnormal seedlings (Dunwell et al., 2010).

Various techniques have been applied to detect haploids. A conventional yet economical approach is by screening their phenotypic features, which reports indicate are stunted and having off-type characteristics due to the chromosome aberration (Yahata et al., 2005). Another approach, chromosome counting, is also conventional and reliable. The haploid has only a half set of chromosomes. In 
E. guineensis, chromosome counting was established by Madon et al. (1995), who found $2 n=32$ chromosomes categorised into three groups - one long, eight medium and seven short pairs, with the chromosomes sizes ranging from 1.00-3.89 $\mu \mathrm{m}$. Other than these conventional approaches, flow cytometry (FCM), a technique used to detect and measure physical and chemical characteristics of cells has become the method of choice to measure the deoxyribonucleic acid (DNA) content and ploidy level in plants (Dolezel et al., 2007). For this reason, FCM is a reliable and fast method to identify haploid plants and has been manipulated as a high-throughput method to screen numerous plant species with various ploidy levels (Ochatt, 2008; Nasution et al., 2013).

The oil palm (Elaeis guineensis Jacq.) is a productive and versatile oil crop with a diploid genome. This perennial produces $36.5 \%$ of the total world vegetable oils - 75.5 million tonnes in 2019, even higher than soyabean, the previous major producer (MPOB, 2019). The demand for palm oil for both edible and non-edible uses is expected to increase with the growing world population. However, improving the crop is difficult due to its long reproductive cycle (10-15 years per breeding generation) and sheer size, requiring huge areas from the breeding trials (Seng et al., 2016). Hence, to overcome such hurdles, biotechnology means or other related techniques that can boost advanced breeding efficiency should be applied. Thus, in this study, a reliable and straightforward approach is proposed for the medium-scale screening for oil palm haploids at the nursery stage to facilitate oil palm breeding.

\section{MATERIALS AND METHODS}

\section{Plant Materials}

A total of 6400 abnormal germinated seeds from advanced breeding materials and germplasm were obtained from crosses of DxD, DxP, (OxP)xP and TxT (D: dura; P: pisifera; O: oleifera T: tenera fruit form) at MPOB Kluang Research Station, Johor, Malaysia.

\section{Morphological Screening of Natural Haploids}

Identification of naturally occurring haploid was initiated with seed morphology screening. Two phases of morphological screening on abnormal germinated seeds/seedlings were performed in this study. The first screening was performed according to Wan Ibrahim et al. (2011) based on 12 'off-type' morphological characteristics of germinated seeds. The seed characteristics involved in this screening are described in Figure 1. The classified abnormal germinated oil palm seeds were then planted according to their abnormal categories. This was followed by the second morphological screening on the three-month-old seedlings based on three characteristics: stunted growth (small size of leaves and height), grassy (narrow and erect grass-like leaves) and, rolled (coiled leaves and twisted stem) leaves (Figure 2). Any normal seedlings (typically with 3-4 dark green leaves) were discarded. Ploidy analysis of the abnormal seedlings was carried out with a FACSCalibur ${ }^{\mathrm{TM}}$ flow cytometer (Becton Dickinson, USA).

\section{Ploidy Level Analysis}

For nuclei preparation, the sampling and processing of leaf samples were performed as described by Madon et al. (2005) with slight modification. Three replicates of each different parts of frond +1 (base, middle and top) were sampled. Each piece $(1.0 \mathrm{~cm} \times 1.0 \mathrm{~cm})$ of leaf was cut to fine slices and incubated in $1.0 \mathrm{ml}$ lysis buffer (LBO1) containing $15 \mathrm{mM}$ ethylenediaminetetraacetic acid, disodium salt ( $\left.\mathrm{Na}_{2} \mathrm{EDTA}\right), 80 \mathrm{mM}$ potassium chloride $(\mathrm{KCI}), 20 \mathrm{mM}$ sodium chloride $(\mathrm{NaCl})$, $0.5 \mathrm{mM}$ spermine, $15 \mathrm{mM} \beta$-mercaptoethanol, 0.15 Triton X-100 (pH 7.5), $50 \mathrm{mg}$ propidium iodide (PI) fluorescent stain and $50 \mu \mathrm{g}$ RNaseA. The diploid oil palm was used as the standard control. The fluorescent intensity of the nuclei was measured using an argon ion laser at $488 \mathrm{~nm}$ in a FACSCalibur ${ }^{\mathrm{TM}}$ flow cytometer (Becton Dickinson, USA). For each sample, the 2C DNA histogram peak obtained from the CellQuest software was compared with 2C DNA content of the standard control.

\section{Chromosome Counting}

The root tips from the germinated seedlings were collected for chromosome preparation. The fresh tips were pre-treated with $2 \mathrm{mM}$ 8-hydroxyquinoline for 5-6 hr and fixed in 3:1 absolute ethanol: glacial acetic acid based on Madon (2000). The roots were then rinsed three times with enzyme buffer ( $0.01 \mathrm{M}$ citric acid-sodium citrate, $\mathrm{pH}$ 4.6). The root cap was removed using a pair of fine forceps under a dissecting microscope (Meiji Stereo). About $1 \mathrm{~cm}$ terminal region from the tip (which included the meristem) was incubated in enzyme mix (2\% cellulose and $20 \%$ pectinase) at $37^{\circ} \mathrm{C}$ for $1-3 \mathrm{hr}$, placed on a glass slide with a drop of $60 \%$ acetic acid, squashed and the debris was removed leaving only a cell suspension. The suspension was covered with a glass cover slip, then tapped a few times and thumb pressure applied to spread out the chromosomes. Next, the cover slip was sealed using nail polish to avoid the specimen from drying. The slide was viewed under 40x magnification of microscope (Carl Zeiss Axioplan, Germany). 


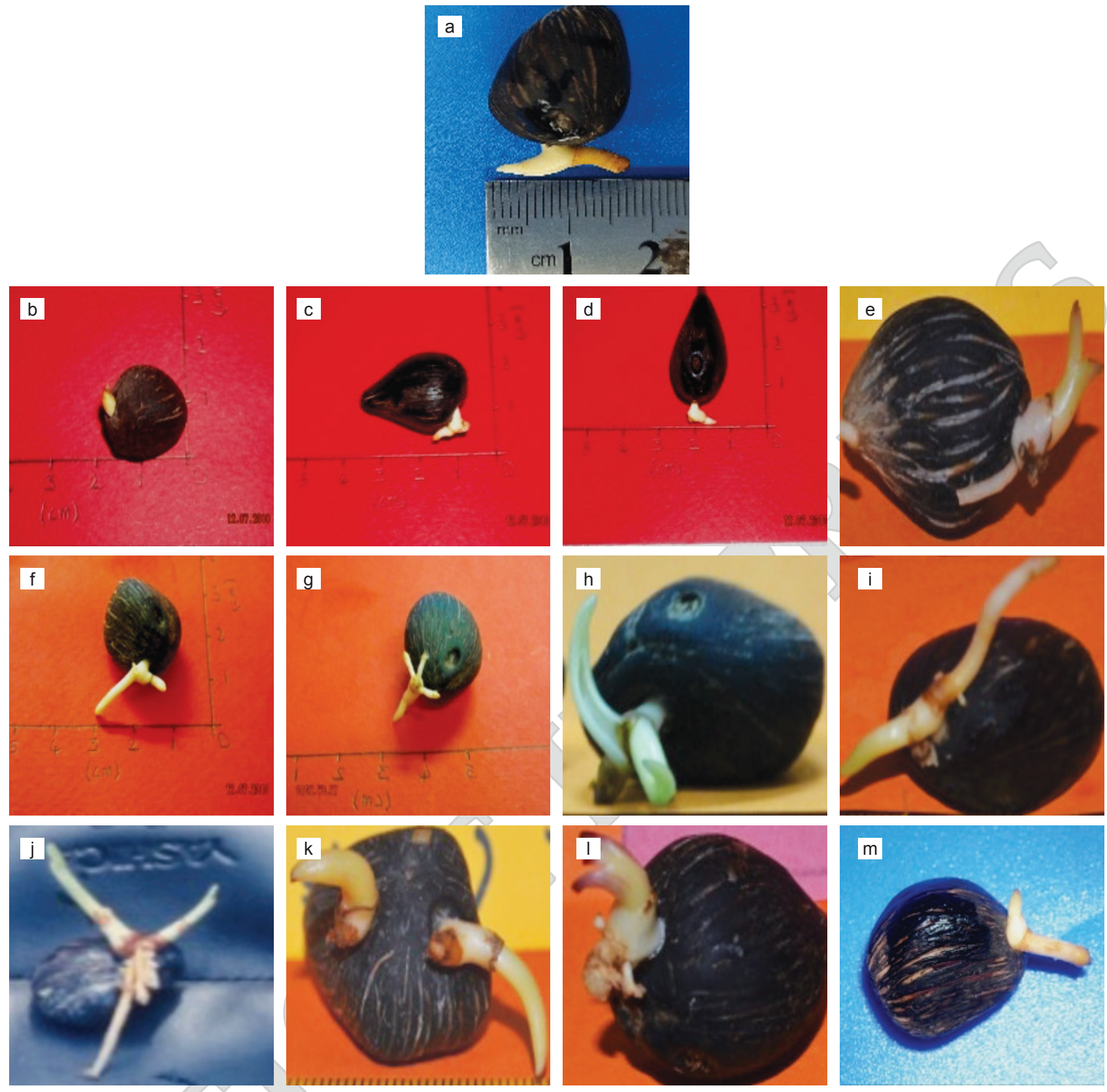

Figure 1. Morphologies of normal and abnormal oil palm germinated seeds. (a) Normal oil palm germinated seeds, (b) stunted plumule, (c) stunted plumule and radicle, $(d)$ stunted radicle, $(e)$ thin radicle, $(f)$ plumule and radicle in $90^{\circ}$ position, $(g)$ branched radicle, $(h)$ branched plumule, $(i)$ ratio of plumule and radicle exceed 1:1, $(j)$ twin seedlings ( $V$-shaped), ( $k$ ) doubleton with stunted plumule/ radicle (seedling has two stunted radicles and plumules), (l) abnormal colour plumule, brownish and ( $m$ ) abnormal colour radicle.
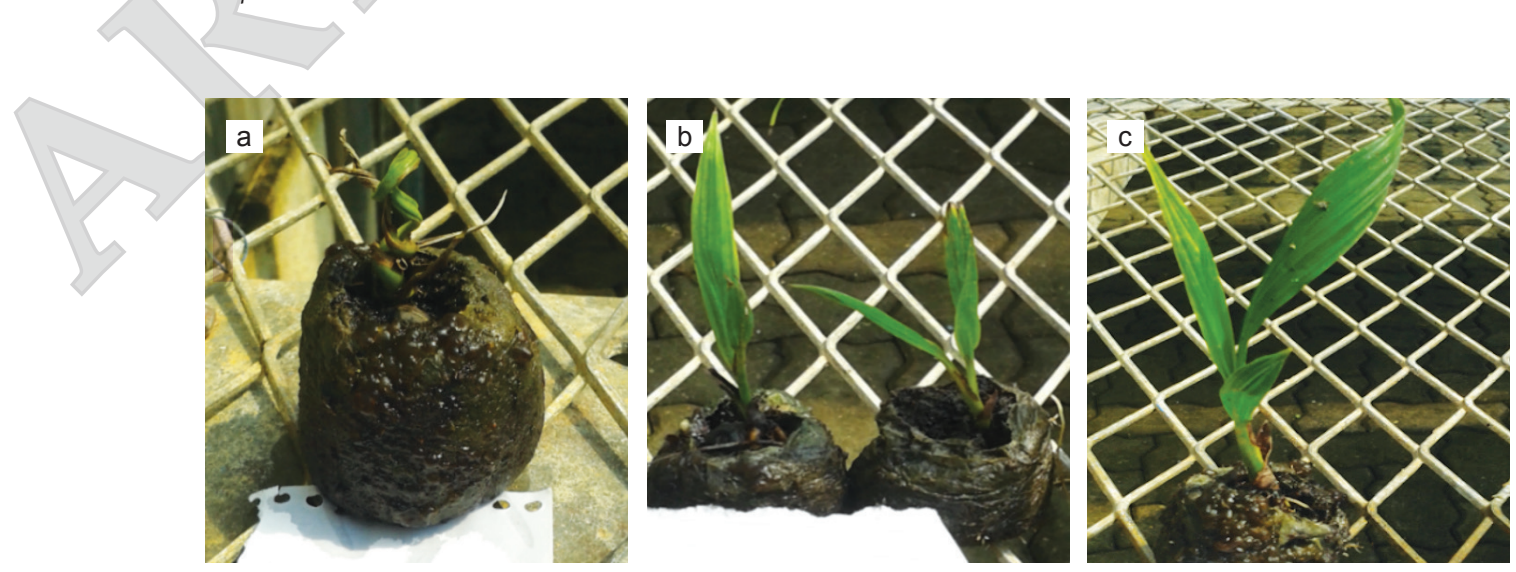

Figure 2. Morphologies of oil palm abnormal seedlings in second stage screening. (a) Stunted, (b) grassy leaves, and (c) rolled leaves. 


\section{DNA Extraction}

Two grams of spear leaves from the haploid plant was ground to a fine powder in liquid nitrogen using mortar and pestle. Genomic DNA was extracted using the modified cetyltrimethylammonium bromide (CTAB) method (Doyle and Doyle, 1990; Suzana et al., 2015). The quality of the DNA was evaluated as described by Rahimah et al. (2006).

\section{Genotyping using SureSawit ${ }^{\mathrm{TM}}$ True-to-Type Single Nucleotide Polymorphism (SNP) Panel}

DNA from the haploid and 15 individual diploid dura $\mathrm{x}$ pisifera (DxP) palms were genotyped using SureSawit ${ }^{\mathrm{TM}}$ True-to-Type SNP panel following the method of Ooi et al. (2019).

\section{RESULTS}

Of the 6400 abnormal germinated seeds examined, the preliminary screening identified 2495 (39\%) with 12 'off-type' morphological characteristics (Figure 1). The subsequent morphological screening of the three-month-old seedlings derived from the 2495 seeds has classified a total of 1346 seedlings with three prominent morphological traits; grassy leaf (673), stunted in growth (520) and seedling with rolled leaves (153). The remaining 1149 possessed other phenotypic features and were discarded.

The 1346 abnormal seedlings identified based on three characteristics (stunted, grassy, rolled leaves) were further analysed for their ploidy level using flow cytometry. Of these, only one haploid with morphology of stunted in both height and size (Figure 3a) was found. The fluorescence intensity peak of sole haploid was observed at channel 130160 (Figure 3d). Chromosome counting confirmed the palm has only 16 chromosomes in the palm (Figure $3 e$ ). Further genotyping with True-to-Type SNP panel showed $100 \%$ homozygous SNP for all its loci tested compared to those of the 15 individual DxP palms. The DxP palms exhibited SNP homozygosity of less than $60 \%$ (Figure 4).

\section{DISCUSSION}

The occurrence of spontaneous haploids is very low. In most studies, haploids are produced by chemical treatment or induced method (Melchinger et al., 2019). It is still not clear how haploids are spontaneously produced. Conceptually, there are several ways, namely spontaneous polyembryony, parthenogenesis and androgenesis (Horlow and Raquin, 1998; Mishra and Gowswami, 2014). Uniparental chromosome elimination as shown in Arabidopsis thaliana (Ravi and Chan, 2010) is another means leading to haploidy, although few studies demonstrated that this occurred in interspecific hybrids (Wedzony et al., 2009; Liu et al., 2014).

Numerous studies have associated abnormal germinated seeds, or 'off types', with haploid formation (Garavello et al., 2019). The actual 'offtype' morphologies observed in germinated seedlings that may be linked to haploid plants have never been described clearly for oil palm. Therefore, a systematic screening for haploids was carried out on a massive pool of abnormal germinated oil palm seeds based on unique morphological characteristics. Such a simple approach, if successful, would be a practical way to obtain haploid oil palm on a medium scale. Moreover, the identification of the exclusive characteristic of the haploid seedlings with additional phenotypic screening may form an ideal and robust approach in identifying haploid individuals. Large numbers of spontaneous haploids and doubled haploids in oil palm were only reported by Dunwell et al. (2010). In our study, the abnormalities such as stunted radicle and plumule were observed during the germination stage prior to the development of the seeds into three-month-old seedlings with stunted height and size compared to the normal palm. This growth habit is similar to that of haploids in other plants (Maluszynska et al., 2003; Aleza et al., 2009).

In addition to morphology screening, several other methods, such as FCM, chromosome counting and SureSawit ${ }^{\mathrm{TM}}$ True-to-Type SNP panel were used to ascertain haploid status. FCM is fast and convenient (Dolezel et al., 2007; Sliwinska, 2018). It robustly determined the ploidy level of the putative haploid in numerous plant research involving induction of haploids and doubled haploids (Gu et al., 2013; Garavello et al., 2019). From the FCM result, the ploidy level was determined by comparing the known ploidy (represented as histogram peak) of a reference plant genome to the unknown species. The 2C DNA histogram peak for a reference diploid oil palm is between 260-320 (Madon et al., 2008). In comparison to the oil palm diploid, a single $2 \mathrm{C}$ DNA histogram peak at the 130-160 channel was detected for the sole haploid palm found (Figure $3 d)$. The classical chromosome counting was also performed to confirm the chromosome number of this haploid. Although cytological analysis is timeconsuming, it is, nevertheless, the most reliable approach to confirm the haploidy of any species as the chromosomes are easily counted in mitotic cells obtained from the root tip (Madon et al., 1998; Zaki et al., 2017). Chromosome counting showed that the candidate haploid palm has 16 chromosomes, half the number of chromosomes in the diploid palm. Furthermore, results from SNP analysis also confirmed the homozygosity of the haploid palm, with only a single allele detected across all the 135 loci tested. With its bi-allelic nature, SNP markers are 

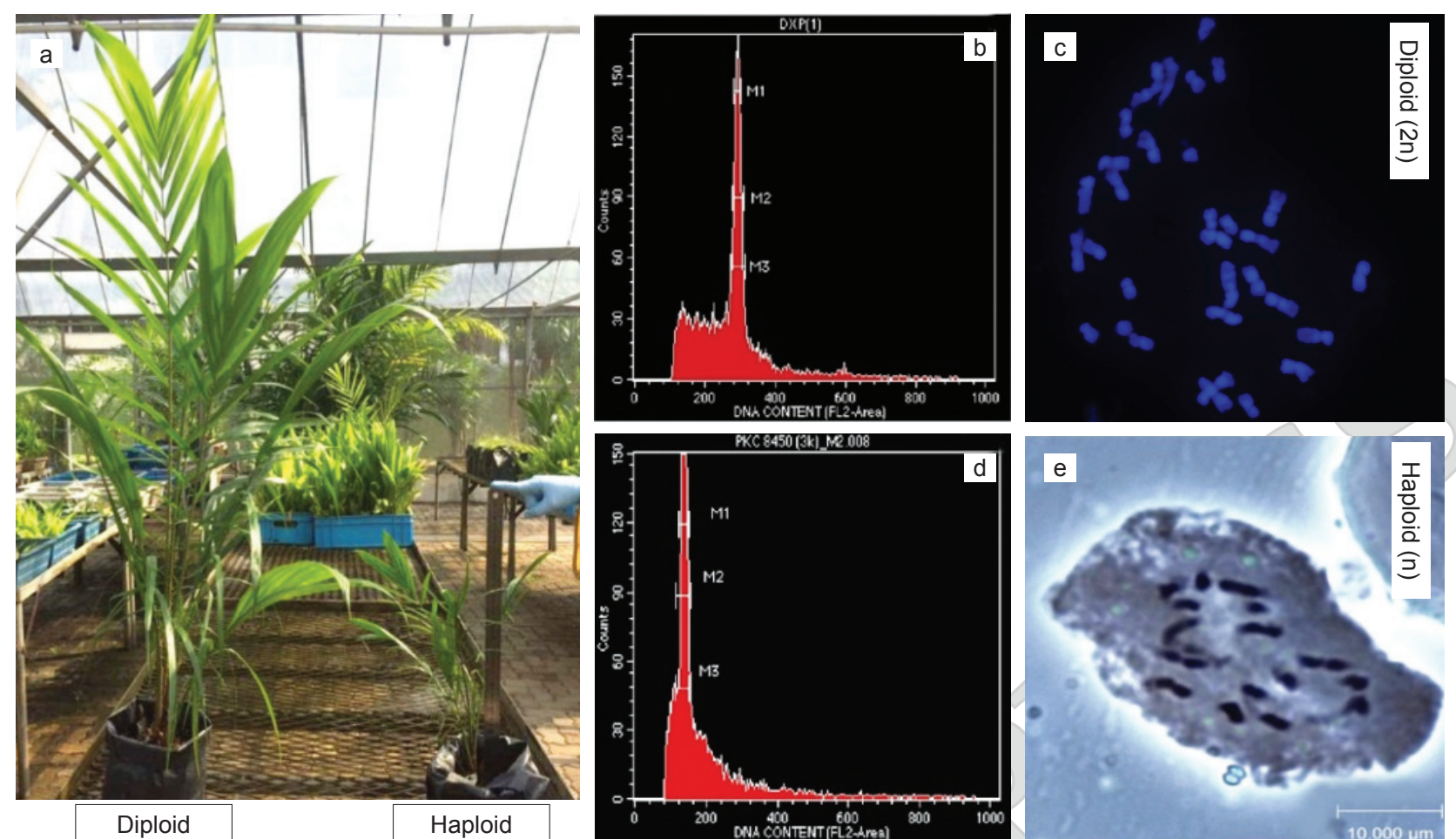

Haploid
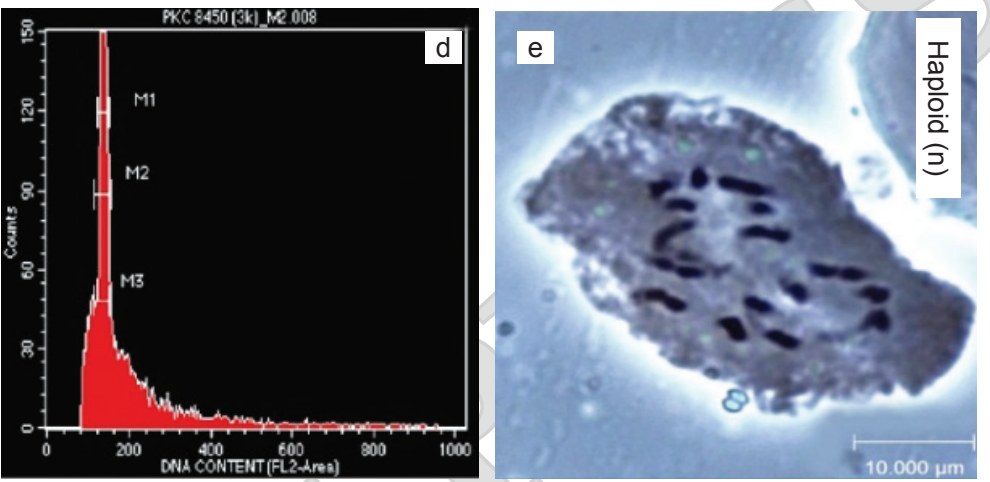

Figure 3. Comparative features of diploid and haploid oil palm. (a) Morphology of normal diploid (left) and stunted haploid (right) oil palm; (b) fluorescent intensity histogram peak of diploid at 260-320 channel; (c) mitotic chromosome preparation showing 32 diploid chromosomes [stained with 4',6-diamidino-2-phenylindole (DAPI)] (bar=10 $\mu \mathrm{m})(\mathrm{d})$ fluorescent intensity histogram peak of haploid at channel 130-160 in flow cytometry analysis; (e) mitotic chromosome preparation showing 16 haploid chromosomes (bar $=10 \mu \mathrm{m}$ ).

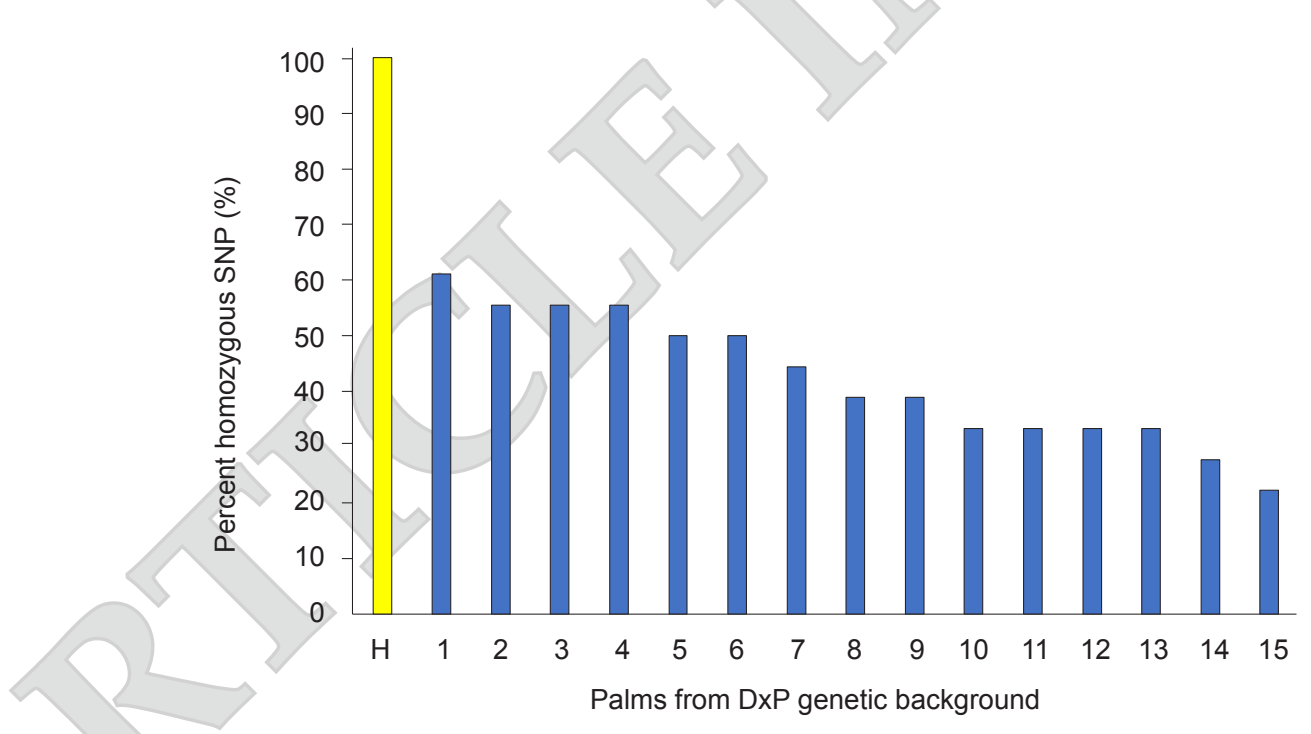

Note: SNP - single nucleotide polymorphism

Figure 4. Genotyping of haploid palm (H) and 15 DxP palms (1-15) using True-to-Type SNP panel.

easier to use than microsatellite markers as reported by Mammadov et al. (2012).

This article provides a simple, systematic and robust approach for identification of spontaneous oil palm haploids. As an alternative approach to Dunwell et al. (2010), this study established three steps screening at smaller scale, comprising of morphological screening of germinated seeds and seedlings with the potential exclusive characteristics, verification of ploidy level with FCM, and cytological analysis to validate the haploid chromosome number.

Moreover, the substitution of massive simple sequence repeat (SSR) screening to True-to-Type SNP panel in determining the homozygosity of haploid candidate is another beneficial alternative in simplifying the spontaneous haploid screening process as a whole. 


\section{CONCLUSION}

This study provides information on the identification of natural haploids in oil palm. Improvement in the approach is critical for haploid production in oil palm. FCM, chromosome counting and SNP analysis used here, can be applied as haploid detection tools in oil palm. Early detection of haploids at seed germination stage will benefit oil palm breeders.

\section{ACKNOWLEDGEMENT}

The authors would like to thank the DirectorGeneral of MPOB for permission to publish this article. We would also like to thank Zainab Anip, Mohamad Razali Mohd Nor and the MPOB Breeding team for their technical assistance in sampling and lab work.

\section{REFERENCES}

Aleza, P; Juárez, J; Hernández, M; Pina, J A; Ollitrault, P and Navarro, L (2009). Recovery and characterization of a Citrus clementina Hort. ex Tan. 'Clemenules' haploid plant selected to establish the reference whole genome citrus. BMC Plant Biology, 9: 110.

Blakeslee, A F (1922). A haploid mutant in the Jimson weed, Datura stramonium. Science, 55: 646-647.

Chaikam, V; Molenaar, W; Melchinger, A E and Boddupalli, P M (2019). Doubled haploid technology for line development in maize: Technical advances and prospects. Theor. Appl. Genet., 132:3227-3243.

Chase, S S (1969). Monoploids and monoploidderivatives of maize (Zea mays L.). Bot. Rev., 35: 117-167.

Dunwell, J M; Wilkinson, M J; Nelson, S; Wening, S; Sitorus, A C; Mienanti, D; Alfiko, Y; Croxford, A D; Ford, C S; Forster, B P and Caligari, P D S (2010). Production of haploids and doubled haploids in oil palm. BMC Plant Biology, 10: 218.

Dolezel, J; Greilhuber, J and Suda, J (2007). Estimation of nuclear DNA content in plants using flow cytometry. Nature Protocols, 2: 2233-2244.

Doyle, J J and Doyle, J L (1990). Isolation of plant DNA from fresh tissue. Focus, 12: 13-15.

Dwivedi, S L; Britt, A B; Tripathi, L; Sharma, S; Upadhyaya, H D and Ortiz, R (2015). Haploids: Constraints and opportunities in plant breeding. Biotechnol. Adv., 33: 812-829.
Garavello, M; Cuenca, J; Dreissig, S; Fuchs, J; Houben, A and Aleza, P (2019). Assessing ploidy level analysis and single pollen genotyping of diploid and euploid citrus genotypes by fluorescence-activated cell sorting and whole-genome amplification. Front. Plant Sci., 10: 1-12.

Germana, M A (2011). Gametic embryogenesis and haploid technology as valuable support to plant breeding. Plant Cell Rep., 30: 839-857.

Gu, C; Liu, Q Z; Yang, Y N; Zhang, S J; Khan, M A; $\mathrm{Wu}, \mathrm{J}$ and Zhang, S L (2013). Inheritance of heterodiploid pollen S-haplotype in self-compatible tetraploid Chinese cherry (Prunus pseudocerasus Lindl). PLoS ONE, 8(4), e61219: 1-10.

Horlow, C and Raquin, C (1998). A critical analysis of existing haploidization techniques. Androgenesis and Haploid Plants (Chupeau, Y; Caboche, M and Henry, $Y$ eds.). Springer, Berlin Heidelberg New York. p. 7-23.

Kostoff, D (1929). An androgenic Nicotiana haploid. Zeitschrift für Zellforschung und Mikroskopische Anatomie, 9: 640-642.

Liu, D; Zhang, H; Zhang, L; Yuan, Z; Hao, M and Zheng, Y (2014). Distant hybridization: A tool for interspecific manipulation of chromosomes. Alien Gene Transfer in Crop Plants (Pratap, A; Kumar, J eds.). Vol. 1: Innovations, Methods and Risk Assessment. Springer. p. 25-42.

Madon, M (2000). Cytogenetical mapping of oil palm chromosomes. Ph.D thesis, Universiti Kebangsaan Malaysia.

Madon, M; Clyde, M M and Cheah, S C (1995). Cytological analysis of Elaeis guineensis (tenera) chromosomes. Elaeis, 7: 122-134.

Madon, M; Clyde, M M and Cheah, S C (1998). Cytological analysis of Elaeis guineensis and Elaeis oleifera chromosomes. J. Oil Palm Res., 10(1): 68-91.

Madon, M; Clyde, M M; Hashim, H; Mohd Yusuf, Y; Mat, $\mathrm{H}$ and Saratha, S (2005). Polyploidy induction of oil palm through colchicine and oryzalin treatments. J. Oil Palm Res., 17: 110-123.

Madon, M; Phoon, L Q; Clyde, M M and Mohd Din, A (2008). Application of flow cytometry for estimation of nuclear DNA content in Elaeis. J. Oil Palm Res., 20: 447-452.

Maluszynska, M; Kasha, K J; Forster, B P and Szarejko, I (2003). Published protocols for other crop plant species. Doubled Haploid Production in 
Crop Plants: A Manual (Maluszynski, M; Kasha, K J; Forster, B P; Szarejko, I eds.). Dordrecht, Kluwer. p. 309-335.

Mammadov, J; Aggarwal, R; Buyyarapu, R and Kumpatla, S (2012). SNP markers and their impact on plant breeding. Int. J. Plant Genomics, 2012: 1-11.

Melchinger, A E; Schipprack, W; Wurschum, T; Chen, S and Technow, F (2019). Rapid and accurate identification of in vivo-induced haploid seeds based on oil content in maize. Scientific Report Nature, 3: 21-29.

Mishra, V K and Gowswami, R (2014). Haploid production in higher plant. Int. J. Chem. Biol. Sci, 1: 26-45.

MPOB (2019). Malaysian Oil Palm Statistics 2019. $39^{\text {th }}$ edition. MPOB, Bangi. p. 185.

Nasution, O; Sitorus, A C; Nelson, S P C; Forster, B P and Caligari, P D S (2013). A high-throughput flow cytometry method for ploidy determination in oil palm. J. Oil Palm Res. Vol. 25(2): 265-271.

Ochatt, S J (2008). Flow cytometry in plant breeding. Cytometry A. PubMed, 73(7): 581-598.

Ooi, LC-L; Low, E-T L; Ordway, J; Marjuni, M; Yaakub, Z; Jiang, N; Smith, S; Bacher, B; Garner, P A; Leinenger, M T; Sander, N; Chan, P L; Ong, P W; Ong-Abdullah, M; Nookiah, R; Abd Manaf, M A; Lakey, N; Sambanthamurthi, R and Singh, R (2019). SureSawit $^{\mathrm{TM}}$ True-to-Type - A high throughput universal single nucleotide polymorphism panel for DNA fingerprinting, purity testing and origin verification in oil palm. J. Oil Palm Res., 31(4): 561-571.

Rahimah, A B; Cheah, S C and Rajinder, S (2006). Freeze-drying of oil palm (Elaeis guineensis) leaf and its effect on the quality of extractable DNA. J. Oil Palm Res., 18: 296-304.

Ravi, M and Chan, S W (2010). Haploid plants produced by centromere mediated genome elimination. Nature, 464: 615-618.
Seng, T; Ritter, E; Mohamed Saad, S H; Leao, L-J; Singh, R; Faridah, Q Z; Tan, S-G; Syed Alwee, S S R and Roa, V (2016). QTLs for oil yield components in an elite oil palm (Elaeis guineensis) cross. Euphytica, 212: 399-425.

Sliwinska, E (2018). Flow cytometry - A modern method for exploring genome size and nuclear DNA synthesis in horticultural and medicinal plant species. Folia Horticulturae, 30: 103-128.

Suzana, M; Rahimah, A R; Maizura, I and Singh, R (2015). A simple and rapid protocol for isolation of genomic DNA from oil palm leaf tissue. J. Oil Palm Res., 27: 282-287.

Wan Ibrahim, W H; Zulkifli, Y; Norziha, A; Rosimah, N and Madon, M (2011). Obtaining oil palm haploids via screening for naturally occurring haploid $(\mathrm{NOH})$ in oil palm germinated seeds and wide hybridization. Proc. of the PIPOC International Palm Oil Congress 2011. MPOB, Bangi.

Wędzony, M; Forster, B P; Żur I; Golemiec, E; Szechyńska-Hebda, M; Dubas, E and Gotebiowska, G (2009). Progress in doubled haploid technology in higher plants. Advances in Haploid Production in Higher Plants (Touraev, A; Forster, B P and Jain, S M eds.). Springer, Dordrecht. p. 1-33.

Xu, L; Najeeb, U; Tang, G X; Gu, H H; Zhang, G Q; He, Y and Zhou, W J (2007). Haploid and doubled haploid technology. Adv. Bot. Res., 45: 181-216.

Yahata, M; Kurogi, H; Kunitake, H; Nagano, K; Yabuya, T; Yamashita, K and Komatsu, H (2005). Evaluation of reproductive functions in a haploid pummelo by crossing with several diploid citrus cultivars. J. Jpn. Soc. Hortic. Sci., 74: 281-288.

Zaki, N M; Singh, R; Nordiana, H M N; Muhammad Azwan, Z; Smith, S W; Schwarzacher, T; Madon, $M$ and Heslop Harrison, J S (2017). Short Communication: Towards development of Elaeis guineensis chromosome - arm specific markers and their utility across the Elaeis genus. J. Oil Palm Res., 29(4): 594-599. 